\title{
On the fractional solubility of copper in marine aerosols: Toxicity of aeolian copper revisited
}

\author{
Edward R. Sholkovitz, ${ }^{1}$ Peter N. Sedwick, ${ }^{2}$ and Thomas M. Church ${ }^{3}$ \\ Received 26 July 2010; revised 8 September 2010; accepted 13 September 2010; published 19 October 2010.
}

[1] Paytan et al. (2009) argue that the atmospheric deposition of aerosols lead to copper concentrations that are potentially toxic to marine phytoplankton in a large area of tropical and subtropical North Atlantic Ocean. A key assumption in their model is that all marine aerosols (mineral dust and anthropogenic particles) have a high $(40 \%)$ fractional solubility of copper. Our data show that the fractional solubility of copper for Saharan dust over the Sargasso Sea and Bermuda is significantly lower (1-7\%). In contrast, anthropogenic aerosols with non-Saharan sources have significantly higher values (10-100\%). Hence, the potential $\mathrm{Cu}$ toxicity in the tropical and subtropical North Atlantic should be re-estimated, given the low fractional solubility of $\mathrm{Cu}$ in the Saharan dust that dominates aerosol deposition to this region. Citation: Sholkovitz, E. R., P. N. Sedwick, and T. M. Church (2010), On the fractional solubility of copper in marine aerosols: Toxicity of aeolian copper revisited, Geophys. Res. Lett., 37, L20601, doi:10.1029/2010GL044817.

\section{Introduction}

[2] Because copper $(\mathrm{Cu})$ is a micro-nutrient required for the growth of marine phytoplankton and a potential toxin, its marine biogeochemistry has received considerable attention [Moffett, 1995; Croot et al., 2000; Morel et al., 2003; Maldonado et al., 2006]. In seawater, copper speciation is dominated by complexation with organic ligands: biological availability and toxicity for marine phytoplankton depend on the dissolved concentration of 'free' inorganic $\mathrm{Cu}$ [Sunda and Guillard, 1976; Anderson and Morel, 1978; Moffett et al., 1990; Moffett and Brand, 1996; Mann et al., 2002]. Paytan et al. [2009] have recently argued that the atmospheric deposition of $\mathrm{Cu}$ to the sea in aerosols could be toxic to phytoplankton in certain open ocean and coastal regions, including large areas of the tropical and subtropical North Atlantic Ocean. Here we examine a critical parameter in their model estimate of copper toxicity; namely, that the fractional solubility of $\mathrm{Cu}$ in aerosols depositing on the sea surface is assumed to be constant at a value of $40 \%$.

\section{Samples and Methods}

[3] Time-series observations have established that aerosols over the western subtropical North Atlantic Ocean are dom-

\footnotetext{
${ }^{1}$ Department of Marine Chemistry and Geochemistry, Woods Hole Oceanographic Institution, Woods Hole, Massachusetts, USA.

${ }^{2}$ Department of Ocean, Earth and Atmospheric Sciences, Old Dominion University, Norfolk, Virginia, USA.

${ }^{3}$ School of Marine Science and Policy, University of Delaware, Newark, Delaware, USA.

Copyright 2010 by the American Geophysical Union. 0094-8276/10/2010GL044817
}

inated by soil dust carried from North Africa ('Saharan dust') during the summer and early fall, with a greatly increased proportion of anthropogenic aerosols carried from North America, Asia and Europe during the period from late fall through spring [Duce and Hoffman, 1976; Chen and Duce, 1983; Arimoto et al., 1995, 2003; Moody et al., 1995; Huang et al., 1999; Prospero, 1999]. This seasonal dichotomy facilitates comparisons between different aerosol types in terms of bulk composition and the fractional solubility of aerosol-borne trace elements [Huang et al., 1999; Sedwick et al., 2007; Sholkovitz et al., 2009; Trapp et al., 2010].

[4] Here we consider chemical data from three types of atmospheric samples collected from the Bermuda region of the Sargasso Sea: (1) bulk ( $>0.5$ micron) aerosol samples collected at sea during 2003-2004 (FeATMISS cruises); (2) bulk aerosol samples collected at Tudor Hill, Bermuda during 2007-2008 (FeAST program); and (3) bulk rainwater samples collected at Tudor Hill during the 2007-2008 FeAST program. The Tudor Hill samples were collected atop a $23 \mathrm{~m}$ tall walk-up tower during periods of onshore wind. Bulk ( $\sim 1$ week integrated composite) rainwater and aerosol samples were collected and processed using the methods described by Kim et al. [1999] and Sedwick et al. [2005, 2007] respectively. The bulk aerosol samples were subjected to a $1: 3 \mathrm{HF} / \mathrm{HNO}_{3}$ digestion prior to the determination of 'total metals'. Unfiltered rainwater samples were acidified to $\mathrm{pH} \sim 1.6$ with $2 \mathrm{~mL} / \mathrm{L}$ of ultra pure hydrochloric acid and then stored for more than 6 months prior to the determination of 'total-dissolvable metals'. Analytical methods are reported by Sedwick et al. [2007], except for $\mathrm{Cu}$, which was determined in aerosol digests, leach solutions and rainwater by inductively-coupled plasma mass spectrometry in the mediumresolution mode.

[5] We also estimate the fractional solubility of copper for aerosols collected at the Tudor Hill tower in 2007 and 2008, using a modification of the flow-through deionized-water leaching protocol described by Buck et al. [2006]. $250 \mathrm{~mL}$ of freshly-produced ultra pure deionized water $(\mathrm{pH} \sim 5.5)$ is rapidly passed through an aerosol-laden $0.4 \mu \mathrm{m}$ polycarbonate filter membrane within several hours of the aerosol sample collection. The filtrate (leachate) was immediately transferred into an acid-cleaned $125 \mathrm{~mL}$ low-density polyethylene bottle and acidified to $\mathrm{pH} \sim 1.6$ with $2 \mathrm{~mL} / \mathrm{L}$ ultra pure hydrochloric acid. The measured concentration of $\mathrm{Cu}$ in this aerosol leachate solution is defined as 'soluble' aerosol $\mathrm{Cu}$, from which a corresponding atmospheric loading of soluble aerosol copper $\left(\mathrm{Cu}_{\mathrm{S}}, \mathrm{ng} \mathrm{m}^{-3}\right)$ was calculated using the total volume of sampled air. From this we calculate the fractional solubility of aerosol copper $\left(\% \mathrm{Cu}_{\mathrm{S}}\right)$, using the total aerosol copper concentration $\left(\mathrm{Cu}_{\mathrm{T}}\right)$ determined for a parallel aerosol sample (see above), as follows: $\% \mathrm{Cu}_{\mathrm{S}}=100\left(\mathrm{Cu}_{\mathrm{S}} / \mathrm{Cu}_{\mathrm{T}}\right)$. 


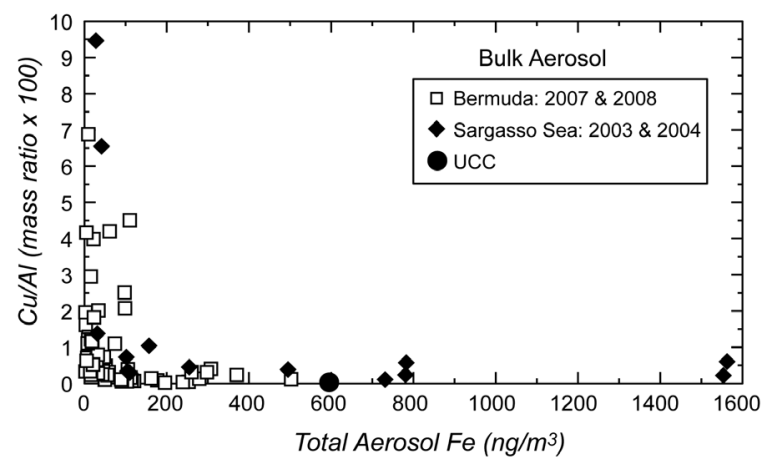

Figure 1. Atmospheric loading of total $\mathrm{Cu} / \mathrm{Al}$ (mass ratio $\times$ $100)$ versus total Fe from analysis of bulk aerosols collected at the Tudor Hill tower (Bermuda) in 2007-2008 and the adjacent Sargasso Sea in 2003-2004. Also plotted is the $\mathrm{Cu} / \mathrm{Al}$ mass ratio $\times 100(=0.03)$ for the upper continental crust (UCC) reported by Taylor and McLennan [1985]. Not shown are four data points with high $\mathrm{Cu} / \mathrm{Al}$ ratios that are off scale with respect to the $\mathrm{y}$-axis; these data reflect aerosol samples with a low load of total iron and a $\mathrm{Cu} / \mathrm{Al}$ ratio that greatly exceeds that of the UCC. Samples with $\mathrm{Fe}$ loading over $400 \mathrm{ng} / \mathrm{m}^{3}$ are predominately composed of Saharan dust.

[6] Laboratory studies of aerosol dissolution are unlikely to reproduce the conditions experienced by aerosol particles deposited to the surface ocean. Hence, such operationallydefined solubility measurements are expected to yield information on the relative solubility of trace elements in aerosols rather than the true fractional solubility of these elements in the surface ocean [Sedwick et al., 2007; Baker and Croot, 2010; Trapp et al., 2010]. Nonetheless, such measurements are thought to provide useful, semi-quantitative information concerning the effective solubility of aerosol trace metals [e.g., Chuang et al., 2005. Sedwick et al., 2005, 2007; Buck et al., 2006, 2010; Trapp et al., 2010]. Moreover, results of a recent study by Aguilar-Islas et al. [2010] indicate that "...different types of aerosols produce more variability in aerosol iron solubility estimates than do different leaching protocols". We assume that the same holds true for operationally-defined estimates of aerosol copper solubility, thus allowing the direct comparison of such estimates between different studies, including our estimates and the values used in the model by Paytan et al. [2009].

\section{Results and Discussion}

[7] Figures 1- 3 show the $\mathrm{Cu}$ data for our bulk aerosol samples (Figure 1), bulk rain samples (Figure 2), and deionized-water leach solutions of bulk aerosols (Figure 3). Total aerosol iron loading, which is presented on the $\mathrm{x}$-axis of Figures 1 and 3, provides a rough measure of the relative proportions of Saharan dust versus non-Saharan aerosols in the Bermuda region of the Sargasso Sea. As discussed by Sedwick et al. [2007] and Sholkovitz et al. [2009], the seasonal shift from high to low aerosol iron loadings in this area corresponds to an increase in the proportion of vanadiumand nickel-rich aerosols carried from North America and other non-Saharan sources. That is, high aerosol Fe loadings are typically associated with the transport of mineral dust from North Africa in the summer months, whereas low

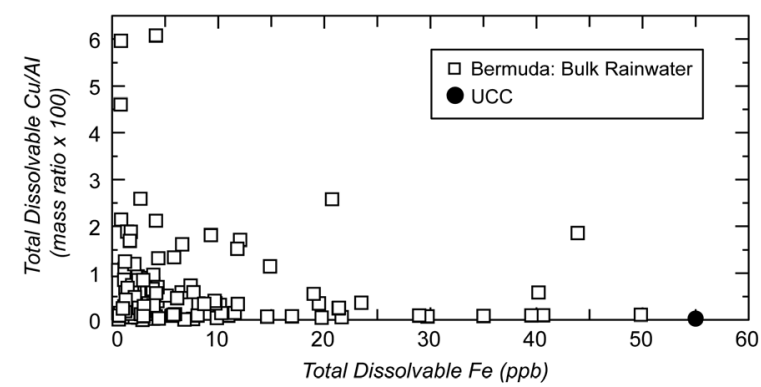

Figure 2. Total-dissolvable $\mathrm{Cu} / \mathrm{Al}$ (mass ratios $\times 100$ ) versus total-dissolvable $\mathrm{Fe}$ in unfiltered bulk rainwater samples collected at the Tudor Hill tower (Bermuda) in 2007-2008. $\mathrm{The} \mathrm{Cu} / \mathrm{Al}($ mass ratio $\times 100$ ) value for UCC refers to the bulk composition of the upper continental crust from Taylor and McLennan [1985].

aerosol Fe loadings are typically associated with a greater proportion of anthropogenic aerosols, primarily carried from North America, from late fall through spring.

[8] It is common geochemical practice to normalize the concentrations of trace elements in aerosols to the concentration of $\mathrm{Al}$, in order to distinguish between mineral aerosols with terrigenous ( crustal) source and those with an anthropogenic source. Figures $1-3$ reveal roughly hyperbolic relationships between total $\mathrm{Cu} / \mathrm{Al}$ and total $\mathrm{Fe}$ in the bulk aerosols (Figure 1); between total-dissolvable $\mathrm{Cu} / \mathrm{Al}$ and total-dissolvable $\mathrm{Fe}$ in rainwater (Figure 2); and between the fractional solubility of aerosol $\mathrm{Cu}$ and total aerosol $\mathrm{Fe}$ (Figure 3). There is a significant increase in the $\mathrm{Cu} / \mathrm{Al}$ mass ratio of bulk aerosols and rainwater from nearly crustal values at high total Fe loadings to values that are well above the crustal ratio at low total Fe loadings. The majority of our aerosol and rainwater samples with crust-like $\mathrm{Cu} / \mathrm{Al}$ ratios were collected in the summer months, when Saharan dust dominates the bulk aerosol near Bermuda. In contrast, the majority of aerosols with $\mathrm{Cu} / \mathrm{Al}$ ratios greater than crustal values were collected in the late fall-spring period, when total aerosol Fe loadings are mostly less than $100 \mathrm{ng} \mathrm{m}^{-3}$ and non-Saharan aerosols account for a larger proportion of the

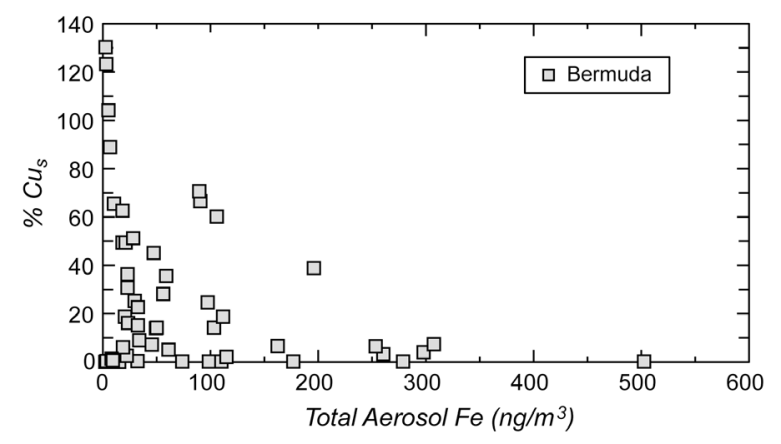

Figure 3. Fractional solubility of aerosol copper in deionized water $\left(\% \mathrm{Cu}_{\mathrm{S}}\right)$ versus total aerosol iron loading for bulk aerosol samples collected at the Tudor Hill tower (Bermuda) in 2007-2008. The two samples with $\% \mathrm{Cu}_{\mathrm{S}}$ values between $120 \%$ and $130 \%$ reflect the large error involved in calculations using low concentrations of similar magnitudes (here soluble $\mathrm{Cu}$ and total aerosol $\mathrm{Cu}$ ). 
bulk aerosol [Sholkovitz et al., 2009]. The orders of magnitude range in $\mathrm{Cu} / \mathrm{Al}$ ratios at low Fe loadings reflects multiple sources of aerosol $\mathrm{Cu}$, including anthropogenic emissions, soil dust and biomass combustion.

[9] A key finding here is the relatively low fractional solubility of aerosol $\mathrm{Cu}(\sim 1-7 \%)$ in Saharan dust (Figure 3), which dominates the bulk aerosol during summer months, versus the generally elevated fractional solubility of $\mathrm{Cu}(\sim 10$ $100 \%$ ) in aerosols collected during the non-summer months, when anthropogenic emissions from North America and other sources account for a greater proportion of the bulk aerosol. The $\% \mathrm{Cu}_{\mathrm{S}}$ and $\mathrm{Cu} / \mathrm{Al}$ data shown in Figures $1-3$ are wholly consistent with our empirical data for the fractional solubility of $\mathrm{V}$ and $\mathrm{Ni}$, and for the bulk aerosol $\mathrm{V} / \mathrm{Al}$ and $\mathrm{Ni} / \mathrm{Al}$ ratios for the 2003-2004 shipboard aerosol samples [Sedwick et al., 2007; Sholkovitz et al., 2009]. Specifically, aerosols in the Bermuda region displayed relatively low fractional solubility values for $\mathrm{V}(\sim 5-7 \%)$ and $\mathrm{Ni}(\sim 1-3 \%)$, and crust-like $\mathrm{V} / \mathrm{Al}$ and $\mathrm{Ni} / \mathrm{Al}$ ratios in summer 2003, when Saharan dust plumes produced high aerosol Fe loadings. In contrast, aerosols collected during spring and early summer 2004, when aerosol Fe loadings were low, displayed elevated fractional solubility values for both $\mathrm{V}(\sim 40-90 \%)$ and $\mathrm{Ni}(\sim 20-40 \%)$, as well as bulk $\mathrm{V} / \mathrm{Al}$ and $\mathrm{Ni} / \mathrm{Al}$ ratios greater than crustal values. It is well known that that $\mathrm{Ni}$ and $\mathrm{V}$ are enriched in oil combustion products, which implies that the fractional solubility of $\mathrm{V}$ and $\mathrm{Ni}$ are elevated in aerosols associated with anthropogenic fuel combustion, relative to Saharan dust.

[10] Following this reasoning, we suggest that both the fractional solubility of $\mathrm{Cu}$ and the bulk $\mathrm{Cu} / \mathrm{Al}$ ratio are elevated in aerosols carried to the Bermuda region from North America and other non-Saharan sources, relative to typical Saharan dust, for which the fractional solubility of $\mathrm{Cu}$ is low $(\sim 1-7 \%)$ and the bulk $\mathrm{Cu} / \mathrm{Al}$ ratio is close to the crustal value. At this stage we lack any direct information concerning the genesis of aerosols that contain relatively soluble $\mathrm{Cu}$ in nonSaharan air masses; fossil fuel combustion and smelting emissions may be important in this regard.

[11] The study of Paytan et al. [2009] is the first attempt to estimate the atmospheric dry deposition flux of $\mathrm{Cu}$ to the ocean on a global scale. They note that their model results are expected to provide a conservative estimate of soluble copper deposition, because wet deposition of $\mathrm{Cu}$ and emissions from copper smelting operations are not considered. Their aerosol transport and deposition model prescribes that $\sim 63 \%$ of the atmospheric dry deposition of $\mathrm{Cu}$ to the ocean is in the form of mineral dust from desert soils, $\sim 5 \%$ is in the form of natural biogenic particles, and $\sim 32 \%$ is in the form of combustion-derived aerosols that are primarily derived from the burning of fossil fuels. From their model simulation of global dry deposition of $\mathrm{Cu}$, Paytan et al. [2009] identify regions where aeolian $\mathrm{Cu}$ accumulates to concentrations that are potentially toxic to native phytoplankton. The largest region where aeolian $\mathrm{Cu}$ is predicted to reach toxic concentrations lies in the tropical and subtropical region of the North Atlantic Ocean, directly under the major transport path of mineral dust from North Africa to Barbados [Prospero, 1999]. Other areas where high concentrations of dissolved $\mathrm{Cu}$ are predicted due to mineral dust deposition include the Mediterranean and Arabian Seas. Paytan et al. [2009] also predict that anthropogenic emissions may lead to toxic dissolved $\mathrm{Cu}$ concentrations in the Bay of Bengal and in two areas of coastal Southeast Asia.
[12] Importantly, the estimate of soluble aeolian $\mathrm{Cu}$ deposition by Paytan et al. [2009] is directly dependent on the assumption that all aerosol-borne $\mathrm{Cu}$, irrespective of source and type, has the same fractional solubility of $40 \%$. This assumption is clearly at odds with our empirical data from the Sargasso Sea, which indicate a much lower fractional solubility $(\sim 1-7 \%)$ for $\mathrm{Cu}$ in Saharan dust, but a higher fractional solubility $(10-100 \%)$ for $\mathrm{Cu}$ in non-Saharan aerosols (Figure 3). In support of their fractional solubility value of $40 \%$, Paytan et al. [2009] cite the study of Chester et al. [1993] who use seawater leaching to estimate the fractional solubility of $\mathrm{Cu}$ in aerosols; their 'crust-rich' aerosols refer to natural mineral dust from the west coast of Africa and the Red Sea; 'urban-rich' aerosols were collected from Liverpool (U.K.) and Corsica; and their 'mixed' aerosols refer to unspecified mixtures of natural and anthropogenic aerosols from the Arabian Sea and Cape Verde. The two sets of crustrich aerosol yield mean fractional solubility values of $1 \%$ and $2 \%$ for $\mathrm{Cu}$, with a range of $<1-4 \%$. The two sets of urbanrich aerosol yield mean fractional solubility values of $30 \%$ and $34 \%$, with a range of $20-54 \%$. The two sets of mixed source aerosol yield intermediate fractional solubility for $\mathrm{Cu}$, with mean values of $13 \%$ and $29 \%$ and a range of 9-33\%. Hence, the aerosol Cu solubility estimates of Chester et al. [1993] agree remarkably well with our Bermuda aerosol data, which suggest a low fractional solubility of $\mathrm{Cu}$ in mineral dust from North Africa, and significantly higher solubility values for anthropogenic aerosols.

[13] Hsu et al. [2005] report mean fractional solubility values of $26 \%$ and $42 \%$ for $\mathrm{Cu}$ in aerosols collected at two sites near the coast of Taiwan. Desboeufs et al. [2005] report fractional solubility values of $36 \%$ and $27 \%$ for $\mathrm{Cu}$ in fly ash from heavy fuel oil and coal, respectively, and a solubility value of $75 \%$ for $\mathrm{Cu}$ in urban particulates. They also report solubility values 'below detection' for $\mathrm{Cu}$ in Arizona soil dust and $28 \%$ for $\mathrm{Cu}$ in Cape Verde loess, the latter sample having a uniquely high fractional solubility among published values for $\mathrm{Cu}$ in mineral dust. Although the potential contributions from multiple sources of non-soildust aerosols renders it difficult to assign a uniform value to $\% \mathrm{Cu}_{\mathrm{s}}$ in combustion emissions, the high values that we have estimated for non-Saharan aerosols and other estimates reported above are in rough accord with the $40 \%$ fractional solubility used by Paytan et al. (2009). Thus, given Paytan et al.'s [2009] model predicts that $\sim 32 \%$ of the total dry deposition of $\mathrm{Cu}$ enters the ocean as combustion emissions, their estimate of the total aeolian flux of soluble $\mathrm{Cu}$ to the global ocean may not be grossly in error; that is, their overly high estimate of $\% \mathrm{Cu}_{\mathrm{s}}$ for soil dust may be offset by a relatively high fractional solubility $(>40 \%)$ of $\mathrm{Cu}$ in combustion aerosols. However, the assumption of constant $\% \mathrm{Cu}_{\mathrm{s}}$ will clearly introduce error in the predicted distribution of soluble $\mathrm{Cu}$ deposition on a regional basis.

\section{Conclusion}

[14] Based on our empirical data from Bermuda in the Sargasso Sea and a reassessment of data published in the literature, we conclude that the fractional solubility of copper in mineral aerosols from North Africa ranges from 1 to $7 \%$. The model-based conclusions of Paytan et al. [2009] assume that the fractional solubility of aerosol copper in the surface ocean is constant at $40 \%$, irrespective of the type and source 
of the copper-bearing aerosols. Our data suggest that modelresults for $\mathrm{Cu}$ toxicity need to more accurately consider the large range in the fractional solubility of aerosol- $\mathrm{Cu}$ being deposited in the coastal and open ocean. In particular, potential $\mathrm{Cu}$ toxicity in the tropical and subtropical region of the North Atlantic should be re-estimated, given the apparently low fractional solubility of $\mathrm{Cu}$ in the Saharan dust that dominates aerosol deposition to this region. On the other hand, we estimate moderate to high values $(10-100 \%)$ for the fractional solubility of copper in anthropogenic aerosols sampled in the Bermuda region that are consistent with the $40 \%$ solubility value assumed by Paytan et al. [2009]. Hence, aeolian inputs to the ocean might result in dissolved $\mathrm{Cu}$ concentrations that are toxic to marine phytoplankton, but we would argue that this situation is likely to be observed only in areas that are strongly impacted by human emissions, rather than open ocean regions where aerosol $\mathrm{Cu}$ deposition is dominated by desert dust.

[15] Acknowledgments. This research was supported by U.S. National Science Foundation (Chemical Oceanography) grants OCE549954 (E.R.S), OCE-0222053 and OCE-0550594 (P.N.S) and OCE0222046 and OCE-0550592 (T.M.C). We gratefully acknowledge the contributions of Chris Marsay and Mak Saito, the review of Peter Croot, as well as the efforts of the officers, crew and marine technicians of the $\mathrm{R} / \mathrm{V}$ Weatherbird II.

\section{References}

Aguilar-Islas, A. M., J. Wu, R. Rember, A. M. Johansen, and L. M. Shank (2010), Dissolution of aerosol-derived iron in seawater: Leach solution chemistry, aerosol type, and colloidal iron fraction, Mar. Chem., 120, 25-33, doi:10.1016/j.marchem.2009.01.011.

Anderson, D. M., and F. M. M. Morel (1978), Copper sensitivity of Gonyaulax tamarensis, Limnol. Oceanogr., 23, 283-295, doi:10.4319/ lo.1978.23.2.0283.

Arimoto, R., R. A. Duce, B. J. Ray, W. G. Ellis Jr., J. D. Cullen, and J. T. Merrill (1995), Trace elements in the atmosphere over the North Atlantic, J. Geophys. Res., 100, 1199-1213, doi:10.1029/94JD02618.

Arimoto, R., R. A. Duce, B. J. Ray, and U. Tomza (2003), Dry deposition of trace elements to the western North Atlantic, Global Biogeochem. Cycles, 17(1), 1010 doi:10.1029/2001GB001406.

Baker, A. R., and P. L. Croot (2010), Atmospheric and marine controls on aerosol iron solubility in seawater, Mar. Chem., 120, 4-13, doi:10.1016/ j.marchem.2008.09.003.

Buck, C. S., W. M. Landing, J. A. Resing, and G. T. Lebon (2006), Aerosol iron and aluminum solubility in the northwest Pacific Ocean: Results from the 2002 IOC cruise, Geochem. Geophys. Geosyst., 7, Q04M07, doi:10.1029/2005GC000977.

Buck, C. S., W. M. Landing, J. A. Resing, and C. I. Measures (2010), The solubility and deposition of aerosol $\mathrm{Fe}$ and other trace elements in the North Atlantic Ocean: Observations from the A16N CLIVAR/CO repeat hydrography section, Mar. Chem., 120, 57-70, doi:10.1016/j. marchem.2008.08.003.

Chen, L., and R. A. Duce (1983), The sources of sulfate, vanadium and mineral matter in aerosol particles over Bermuda, Atmos. Environ., 17, 2055-2064, doi:10.1016/0004-6981(83)90362-1.

Chester, R. K., K. J. T. Murphy, F. J. Lin, A. S. Berry, G. A. Bradshaw, and P. A. Corcoran (1993), Factors controlling the solubilities of trace metals from non-remote aerosols to the sea surface by the 'dry' deposition mode, Mar. Chem., 42, 107-126, doi:10.1016/0304-4203(93)90241-F.

Chuang, P. Y., R. M. Duval, M. M. Shafer, and J. J. Schaur (2005), The origin of water soluble particulate iron in the Asian atmospheric outflow, Geophys. Res. Lett., 32, L07813, doi:10.1029/2004GL021946.

Croot, P. L., J. W. Moffett, and L. E. Brand (2000), Production of extracellular $\mathrm{Cu}$ complexing ligands by eucaryotic phytoplankton in response to Cu stress, Limnol. Oceanogr., 45, 619-627, doi:10.4319/ 10.2000.45.3.0619.

Desboeufs, K. V., A. Sofikitis, R. Losno, J. L. Colin, and P. Ausset (2005), Dissolution and solubility of trace metals from natural and anthropogenic aerosol particulate matter, Chemosphere, 58, 195-203, doi:10.1016/ j.chemosphere.2004.02.025.

Duce, R. A., and G. L. Hoffman (1976), Atmospheric vanadium transport to the ocean, Atmos. Environ., 10, 989-996, doi:10.1016/0004-6981(76) 90207-9.

Hsu, S.-C., F.-J. Li, and W.-L. Jeng (2005), Seawater solubility of natural and anthropogenic metals within aerosols collected from Taiwan coastal sites, Atmos. Environ., 39, 3989-4001, doi:10.1016/j.atmosenv. 2005.03.033.

Huang, S., K. A. Rahn, R. Arimoto, W. C. Graustein, and K. K. Turekian (1999), Semiannual cycles of pollution at Bermuda, J. Geophys. Res., 104, 30,309-30,317, doi:10.1029/1999JD900801.

Kim, G., L. Alleman, and T. M. Church (1999), Atmospheric depositional fluxes of trace elements, ${ }^{7} \mathrm{Be}$, and ${ }^{210} \mathrm{~Pb}$ to the Sargasso Sea, Global Biogeochem. Cycles, 13, 1183-1192, doi:10.1029/1999GB900071.

Maldonado, M. T., et al. (2006), Copper-dependent iron transport in coastal and oceanic diatoms, Limnol. Oceanogr., 51, 1729-1743, doi:10.4319/ lo.2006.51.4.1729.

Mann, E. L., N. Ahlgren, J. W. Moffett, and S. W. Chisholm (2002), Copper toxicity and cyanobacteria ecology in the Sargasso Sea, Limnol. Oceanogr., 47, 976-988, doi:10.4319/1o.2002.47.4.0976.

Moffett, J. W. (1995), Temporal and spatial variability of copper complexation by strong chelators in the Sargasso Sea, Deep Sea Res., Part I, 42, 1273-1295, doi:10.1016/0967-0637(95)00060-J.

Moffett, J. W., and L. E. Brand (1996), Production of strong, extracellular $\mathrm{Cu}$ chelators by marine cyanobacteria in response to $\mathrm{Cu}$ stress, Limnol. Oceanogr., 41, 388-395, doi:10.4319/1o.1996.41.3.0388.

Moffett, J. W., R. G. Zika, and L. E. Brand (1990), Distribution and potential sources and sinks of copper chelators in the Sargasso Sea, Deep Sea Res., Part A, 37, 27-36, doi:10.1016/0198-0149(90)90027-S.

Moody, J. L., S. J. Oltsman, H. Levy, and J. T. Merrill (1995), Transport climatology of tropospheric ozone: Bermuda, 1988-1991, J. Geophys. Res., 100, 7179-7194, doi:10.1029/94JD02830.

Morel, F. M. M., A. J. Milligan, and M. A. Saito (2003), Marine bioinorganic chemistry: The role of trace metals in the oceanic cycles of major nutrients, in Treatise on Geochemistry, vol. 6, The Oceans and Marine Geochemistry, pp. 113-143, Elsevier, Amsterdam.

Paytan, A., et al. (2009), Toxicity of atmospheric aerosols on marine phytoplankton, Proc. Natl. Acad. Sci. U. S. A., 106, 4601-4605, doi:10.1073/ pnas.0811486106.

Prospero, J. M. (1999), Long-term measurements of the transport of African mineral dust to the southeast United States: Implications for regional air quality, J. Geophys. Res., 104, 15,917-15,927, doi:10.1029/ 1999JD900072.

Sedwick, P. N., T. M. Church, A. R. Bowie, C. M. Marsay, S. J. Ussher, K. M. Achilles, P. J. Lethaby, R. J. Johnson, M. M. Sarin, and D. J. McGillicuddy (2005), Iron in the Sargasso Sea (Bermuda Atlantic Time-series Study region) during summer: Eolian imprint, spatiotemporal variability, and ecological implications, Global Biogeochem. Cycles, 19, GB4006, doi:10.1029/2004GB002445.

Sedwick, P., E. R. Sholkovitz, and T. M. Church (2007), Impact of anthropogenic combustion emissions on the fractional solubility of aerosol iron: Evidence from the Sargasso Sea, Geochem. Geophys. Geosyst., 8, Q10Q06, doi:10.1029/2007GC001586.

Sholkovitz, E. R., P. N. Sedwick, and T. M. Church (2009), Influence of anthropogenic combustion emissions on the atmospheric deposition of soluble aerosol iron to the oceans: Empirical estimates for island sites in the North Atlantic Ocean, Geochim. Cosmochim. Acta, 73, 3981-4003, doi:10.1016/j.gca.2009.04.029.

Sunda, W. G., and R. R. L. Guillard (1976), The relationship between cupric ion activity and toxicity of copper to phytoplankton, Limnol. Oceanogr., 47, 976-988.

Taylor, S. R., and S. M. McLennan (1985), The Continental Crust: Its Composition and Evolution, Blackwell Sci., Oxford, U. K.

Trapp, J. M., F. J. Millero, and J. M. Prospero (2010), Trends in the solubility of iron in dust-dominated aerosols in the equatorial Atlantic trade winds: Importance of iron speciation and sources, Geochem. Geophys. Geosyst., 11, Q03014, doi:10.1029/2009GC002651.

T. M. Church, School of Marine Science and Policy, University of Delaware, Newark, DE 19716, USA.

P. N. Sedwick, Department of Ocean, Earth and Atmospheric Sciences, Old Dominion University, 4600 Elkhorn Ave., Norfolk, VA 23529, USA.

E. R. Sholkovitz, Department of Marine Chemistry and Geochemistry, Woods Hole Oceanographic Institution, Mail Stop 25, Woods Hole, MA 02543, USA. (esholkovitz@whoi.edu) 